\title{
Modulation of telomerase activity by telomere DNA-binding proteins in Oxytricha
}

\author{
Stacie J. Froelich-Ammon, ${ }^{1}$ Brent A. Dickinson, ${ }^{1}$ Joanne M. Bevilacqua, ${ }^{2}$ Steve C. Schultz, and \\ Thomas R. Cech ${ }^{3}$ \\ Department of Chemistry and Biochemistry and Howard Hughes Medical Institute, University of Colorado, Boulder, \\ Colorado 80309-0215 USA
}

Telomere proteins protect the chromosomal terminus from nucleolytic degradation and end-to-end fusion, and they may contribute to telomere length control and the regulation of telomerase The current studies investigate the effect of Oxytricha single-stranded telomere DNA-binding protein subunits $\alpha$ and $\beta$ on telomerase elongation of telomeric DNA. A native agarose gel system was used to eval uate telomere DNA-binding protein complex composition, and the ability of telomerase to use these complexes as substrates was characterized. Efficient elongetion occurred in the presence of the $\alpha$ subunit. Moreover, the $\alpha$-DNA cross-linked complex was a substrate for telomerase. At higher $\alpha$ concentrations, two $\alpha$ subunits bound to the 16-nucleotide single-stranded DNA substrate and rendered it inaccessible to telomerase. The formation of this $\alpha \cdot$ DNA $\cdot \alpha$ complex may contribute to regulation of telomere length. The $\alpha \cdot \beta \cdot$ DNA temary complex was not a substrate for telomerase. Even when telomerase was prebound to telomeric DNA, the addition of $\alpha$ and $\beta$ inhibited elongation, suggesting that these telomere protein subunits have a greater affinity for the DNA and are able to displace telomerase In addition, the temary complex was not a substrate for teminal deoxynucleotidyltransferase. We conclude that the telomere protein inhibits telomerase by rendering the telomeric DNA inaccessible, thereby helping to maintain telomere length.

[Key Words: Telomere; telomerase; regulation; telomere DN A-binding proteins; Oxytricha]

Received February 2, 1998; revised version accepted M arch 10, 1998.

Telomeres, the protein-DNA complexes at the termini of eukaryotic chromosomes, are vital for the preservation and complete repl ication of the genome (for reviews, see Blackburn 1991; Zakian 1995; Greider 1996). The past few years have seen explosive growth in our knowledge of telomere DNA-binding proteins and of telomerase, the enzyme that synthesizes telomeric DNA (for review, see Lingner and Cech 1998). Much less is known about the interaction between these two macromolecuIar complexes. The mechanisms of tel omere-telomerase interaction provide the subject of the investigations presented here.

Typically telomeric DN A consists of tandem repeats of a short sequence with the guanine-rich strand oriented $5^{\prime} \rightarrow 3^{\prime}$ toward the chromosome terminus (e.g., Oxytricha telomeres consist of $\mathrm{T}_{4} \mathrm{G}_{4}$ repeats; Klobutcher et al. 1981). Although telomere length varies from species to

Present addresses: ${ }^{1}$ Sangamo BioSciences Corporation, Porter Biosciences, Room 0058, University of Colorado, Boulder, Colorado 80309 USA; ${ }^{2}$ Department of Chemistry, Pennsylvania State University, University Park, Pennsylvania 16802 USA.

${ }^{3}$ Corresponding author.

E-MAIL thomas.cech@colorado.edu; FAX (303) 492-6194. species, the protrusion of the G-rich strand as a single stranded overhang is a feature conserved among ciliated protozoa (for review, see Zakian 1989, 1995), yeast (Wellinger et al. 1993, 1996; Zakian 1996), and mammals (Makarov et al. 1997; McElligott and Wellinger 1997; Wright et al. 1997). Thus, despite differences in telomeric sequence and length between species, there may be similar functional mechanisms in telomere maintenance.

In addition to the simple DNA repeats, a number of proteins play integral roles in telomere structure and function. Telomere proteins are of two types: those that bind the double-stranded portion of the telomere and those that bind the single-stranded telomeric overhang (for reviews, see Fang and Cech 1995a; Greider 1996; Brun et al. 1997). The best characterized single-stranded telomeric DNA-binding protein is that of the ciliated protozoan Oxytricha nova; the crystal structure of its complex with telomeric DNA has been solved recently (M. Horvath, V. Schweiker, J. Ruggles, J.M. Bevilacqua, and S.C. Schultz, unpubl.). The protein is a heterodimer consisting of a 56-kD $\alpha$ subunit and a 41-kD $\beta$ subunit (Gottschling and Zakian 1986; Price and Cech 1987). Initial research revealed that the $\alpha$ subunit forms a specific 
Telomere proteins modulate telomerase activity

complex with telomeric DNA, whereas the $\beta$ subunit does not bind to DN A with sequence specificity by itself. The $\alpha$ and $\beta$ subunits together bind tenaciously to telomeric DN A to form a stable ternary complex (Gray et al. 1991).

The $\beta$ subunit is capable of chaperoning the formation of G-quartet structures (Fang and Cech 1993a). G-quartets form monovalent cation-induced tetraplex DNA structures (Williamson 1994), which previously were shown to be poor substrates for telomerase (Zahler et al. 1991). The highly charged carboxyl domain of the $\beta$ subunit mediates G-quartet structure formation in vitro (Fang and Cech, 1993a). The $\alpha \cdot \beta$ heterodimer does not form on DN A folded into G-quartets, but rather requires an unfolded telomeric DNA substrate (Raghuraman and Cech 1990).

One of the functions of the telomere is to act as a substrate for telomerase, the ribonucleoprotein that catalyzes the synthesis of telomeric DNA repeats (for reviews, see Blackburn 1992; Greider 1996; Lingner and Cech 1998). The regulation of telomere length and telomerase activity appear pivotal for cellular life span (Lundblad and Szostak 1989; Harley and Villeponteau 1995; Bodnar et al. 1998). Telomerase and singlestranded tel omere DN A-binding protei ns share substrate specificity (the telomeric DNA overhang). Both Iocalize to the Oxytricha replication band during S-phase (Fang and Cech 1995b), and the tel omere DN A-binding protein localizes behind tel omerase in these anal yses. Thus, it is thought that the telomere protein may bind to newly synthesized telomeres for their protection. A similar situation pertains in Eupl otes crassus, with the interesting additional feature of a replication-specific version of the telomere protein (Skopp et al. 1996).

The effect of the Oxytricha telomere DNA-binding proteins on telomerase activity was studied initially by Shippen et al. (1994). They reported that the ternary complex was a substrate for telomerase, al though not as good a substrate as DN A free in solution. Because these experiments used native proteins that cannot be isolated in large quantities, the integrity of the reconstituted telomere protein-DN A complexes was difficult to evaluate. Moreover, the $\alpha$. DN A complex, although initially characterized by nitrocellulose filter binding and dimethylsulfate (DMS) protection (Gray et al. 1991; Fang et al. 1993), had not been visualized as a discrete complex with the biological DNA substrate by gel electrophoresis.

The present studies used recombinant Oxytricha telomere DNA-binding proteins in conjunction with native agarose gel electrophoresis (J.M. Bevilacqua and S.C. Schultz, unpubl.) to monitor telomere protein complex formation. The effect of telomere protein subunits on the synthesis of telomeric repeats by telomerase was then analyzed. Telomere DNA-binding protein subunits were found to inhibit telomerase by altering the telomeric DNA substrate accessibility and, therefore, may collaborate with telomerase to maintain telomere length. A model of telomere protein involvement in telomere synthesis and length regulation is presented.

\section{Results}

Telomere protein-DNA complex formation

The $\alpha$ and $\beta$ subunits form a stable ternary complex with telomeric DNA, which has been observed as a discrete band by polyacrylami de gel shift anal ysis (Fang and Cech 1993b; Fang et al. 1993). In contrast, the less stable $\alpha$. DN A complex forms smears on polyacrylami de gels and, therefore, has been characterized by nitrocellulose filter binding and DMS protection (Gray et al . 1991; Fang et al. 1993). Many of these previous studies were performed with single-stranded oligonucleotides much larger than the bi ologi cal substrate to counterbal ance the high positive charge inherent to the telomere proteins. To determine which telomere protein - DN A complexes were present and extended by telomerase, a novel agarose gel system was used (J.M. Bevilacqua and S.C. Schultz, unpubl.). Samples are loaded in the center of a horizontal agarose gel, and during el ectrophoresis, the positively charged DNA · protein complexes migrate in one direction, whereas the negatively charged DN A migrates in the opposite direction. This methodology permits the use of the biological length substrate [i.e., the single-stranded 16-mer $\left(\mathrm{T}_{4} \mathrm{G}_{4}\right)_{2}$ ].

Gel-shift analysis resulted in a distinct banding pattern with the addition of increasing concentrations of protein. The addition of the $\alpha$ subunit resulted in formation of $\alpha$. DNA and subsequently $\alpha \cdot$ DNA $\cdot \alpha$ complexes (Fig. 1), as expected from the previous conclusion that two $\alpha$ subunits can bind a two-repeat DNA in a noncooperative fashion (Gray et al . 1991). The transition between the $\alpha \cdot$ DNA and the $\alpha \cdot$ DNA $\cdot \alpha$ complex began to occur beyond $\sim 250 \mathrm{~nm}$. When both $\alpha$ and $\beta$ were added, an additional complex of higher positive charge/

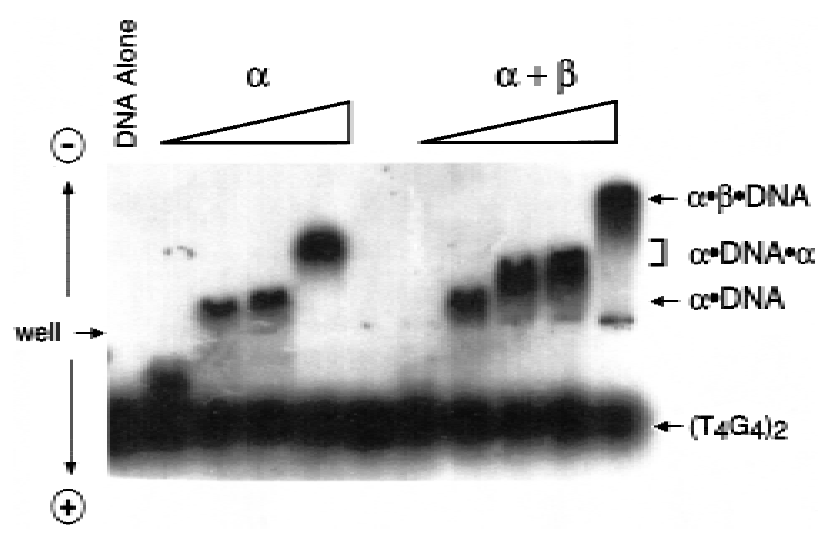

Figure 1. Telomere DNA-binding protein complex formation analyzed by agarose gel electrophoresis. The DNA substrate $\left(\mathrm{T}_{4} \mathrm{G}_{4}\right)_{2}$ was $5^{\prime}$-radiolabeled and was kept at a constant concentration throughout the binding assay $(10 \mathrm{~nm}$, submolar to the protein concentration). The $\alpha$ subunit was present at $25 \mathrm{nM}, 100$ $\mathrm{nM}, 1 \mu \mathrm{M}$, and $2.5 \mu \mathrm{M}$; protein concentrations for formation of the $\alpha \cdot \beta \cdot$ DN A ternary complex were $5 \mathrm{~nm} \alpha$ and $5 \mathrm{~nm} \beta ; 25 \mathrm{~nm}$ $\alpha$ and $10 \mathrm{~nm} \beta ; 250 \mathrm{~nm} \alpha$ and $25 \mathrm{~nm} \beta ; 1 \mu \mathrm{m} \alpha$ and $50 \mathrm{~nm} \beta ; 2.5$ $\mu \mathrm{M} \alpha$ and $100 \mathrm{~nm} \beta$. The data are representative of five experiments. 
mass ratio was formed. The increased mobility of this complex is consistent with the presence of the $\beta$ subunit, which is highly basic (Hicke et al. 1990). Therefore, this complex is identified as the 1:1:1 complex of $\alpha \cdot \beta \cdot$ DN A characterized previously (Fang and Cech 1993b).

Further evidence for the identification of the $\alpha \cdot$ DN A $\cdot \alpha$ complex was obtained by analyzing binding of the $\alpha$ subunit to oligonucleotides containing one and two tel omeric repeats (Fig. 2). Previous DM S protection studies had defined the $\alpha$ subunit binding site as a single $\mathrm{T}_{4} \mathrm{G}_{4}$ repeat (Gray et al . 1991). Consistent with this finding, the putative $\alpha \cdot$ DNA $\cdot \alpha$ complex was observed only with the oligonucleotide containing two telomeric repeats.

Agarose gel electrophoresis does not trap the complexes but allows dissociation within the gel matrix. Therefore, the apparent $K_{d}$ values in the present study may be greater than the actual $K_{d}$ values. At certain concentrations, kinetic transitions between complexes result in intermediate electrophoretic mobilities. However, the complexes that are stable in these gels will be even more stable in solution, where dissociated DNA cannot electrophorese away from the protein.

From these studies, the complexes present at specific concentrations were identified, and the ability of telomerase to exploit these complexes as substrates could be evaluated.

Telomere protein subunits modulate telomerase activity

The ability of telomerase to use telomeric DNA complexed with telomere protein subunits was analyzed. $O$. nova tel omere proteins were prebound to the DN A substrate, followed by the addition of telomerase-containing Oxytricha trifallax nucl ear extract. (The justification for use of the nuclear extract from a different species of Oxytricha is given in a subsequent section.) The synthesis of tel omeric repeats was monitored by denaturing gel

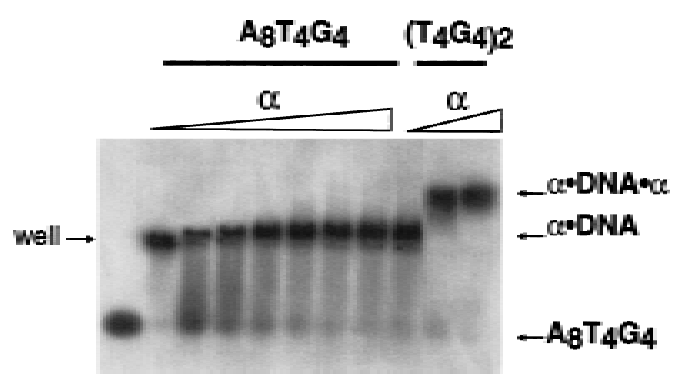

Figure 2. An $\alpha$ subunit binds to each $\mathrm{T}_{4} \mathrm{G}_{4}$ repeat forming an $\alpha \cdot$ DNA $\cdot \alpha$ complex on the native telomeric sequence. The oligonucleotide $\mathrm{A}_{8} \mathrm{~T}_{4} \mathrm{G}_{4}$, which has only one telomeric-binding register, was used to analyze the binding of the $\alpha$ subunit. The oligonucl eotide was present at a constant concentration of $1 \mathrm{~nm}$. The $\alpha$ subunit was present at 10, 25, 50,100, and $500 \mathrm{~nm}$, and at 1 and $2.5 \mu \mathrm{m}$. The three right lanes are binding analyses with the natural sequence oligonucleotide $\left(\mathrm{T}_{4} \mathrm{G}_{4}\right)_{2}$ at $\alpha$ concentrations of $0.25,1$, and $5 \mu \mathrm{m}$.
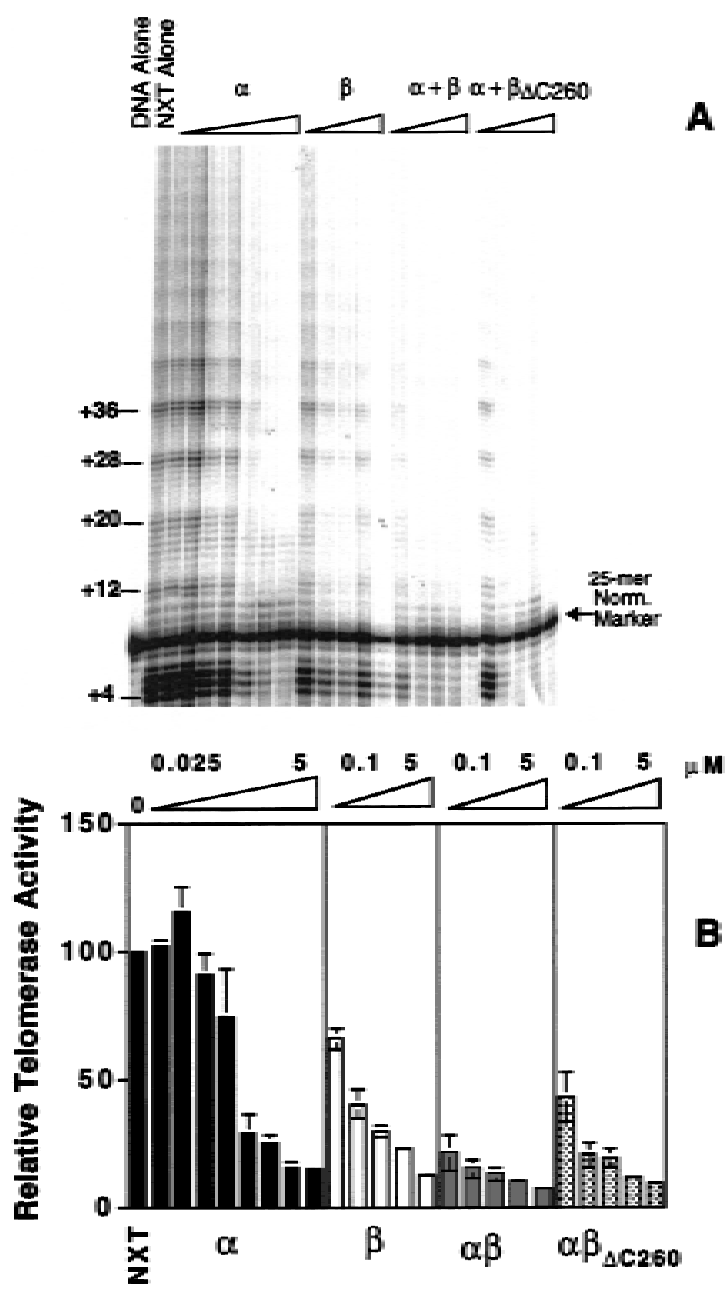

Figure 3. Telomere protein modulation of telomerase el ongation of telomeric DNA. (A) A telomerase activity assay was performed with 5'-radiolabeled DNA substrate $\left(T_{4} \mathrm{G}_{4}\right)_{2}$ in the presence of the telomere protein subunits. $\alpha, \beta$, or $\alpha+\beta$ were preincubated with DNA, followed by the addition of tel omerase and nucleotides. The $\beta$ subunit was present at the following concentrations: $0.025,0.050,0.1,0.25,0.5,1,2.5$, and $5 \mu \mathrm{m}$. The $\alpha$ subunit was present at $0.1,0.25,0.5,1$, and $5 \mu \mathrm{m}$. In studies with the $\alpha+\beta$ and $\alpha+\beta_{\Delta C 260}$, both subunits were present at 0.1 , $0.25,0.5,1$, and $5 \mu \mathrm{M}$. A 25 -mer ol igonucl eoti de was added after the reaction was stopped but before ethanol precipitation, serving as a size marker and for internal normal ization during quantification. (B) The bar graph quantifies the effects of $O$. trifallax tel omere protein on tel omerase activity. $\beta_{\Delta C 260}$ denotes a truncated version of the $\beta$ subunit (thelysine-rich carboxyl terminus is deleted). Standard deviations for three independent experiments are depicted by the error bars.

electrophoresis and quantified relative to an internal normalization marker (Fig. 3).

In the absence of telomere protein, telomerase added multiple repeats to the $\left(\mathrm{T}_{4} \mathrm{G}_{4}\right)_{2}$ primer. Given the large excess of unlabeled primer, this indicates that the DNA substrate bound initially remains bound through additional rounds of extension (i.e., the extension is processive). Telomerase was al so able to extend the DN A in the 
presence of up to $250 \mathrm{~nm} \alpha$ subunit. In this concentration range the $\alpha$. DNA complex was formed, as verified by agarose gel electrophoresis. At higher concentrations of the $\alpha$ subunit, where the $\alpha \cdot$ DNA $\cdot \alpha$ complex was the predominant species, extension was greatly diminished.

In the presence of the $\beta$ subunit al one the level of telomerase activity was decreased. Telomerase activity is known to be attenuated in the presence of G-quartet structures (Zahler et al. 1991), and the $\beta$ subunit carboxy-terminal domain is known to mediate the formation of these structures (Fang and Cech 1993a). Consistent with this interpretation, when a truncated $\beta$ subunit $\left(\beta_{\Delta C 260}\right)$ with the carboxy-terminal domain deleted is used, the effect of the protein on extension is minimal (see last section of Results).

The ability of telomerase to elongate tel omeric DN A is attenuated and eliminated rapidly with increasing concentrations of both the $\alpha$ and $\beta$ subunits (Fig. 3). When a ternary complex is formed in the presence of the $\alpha$ subunit and a $\beta_{\Delta c 260}$ subunit, telomerase activity is also abolished, but the reduction in activity occurs at higher protein concentrations. This result suggests that the carboxyl terminus of the $\beta$ subunit may play a role in ternary complex stabilization or exclusion of tel omerase.

The modulation of telomerase activity is telomere protein specific

To test whether the influence on telomerase activity was specific to telomere DN A-binding protein subunits, a titration, analogous to that performed with the telomere proteins (Fig. 3), was completed with bovine serum albumin (BSA) (Fig. 4A). Even at the highest concentration $(5 \mu \mathrm{M})$ of BSA, there was no effect on telomerase activity. Because the telomere protein subunits are highly basic, the identical experiment was performed with cytochrome c, a very basic protein that binds nonspecifically to single and double-stranded DNA (Fig. 4B). Again, there was no effect on telomerase activity.

Telomere protein displaces tel omerase bound to telomeric DNA

Because the telomere protein-DNA ternary complex is not elongated by telomerase, it was hypothesized that the telomere proteins may provide a mechanism of length regulation. In theory, this could be accomplished by the displacement of telomerase by the telomere protein after synthesis of a desired number of repeats. To investigate the ability of telomere protein subunits to di splace telomerase in a specific fashion, telomerase was prebound to a 5'-radiolabeled DNA substrate in the absence of nucleotides. Telomere protein and nucleotides were then added to initiate the reaction. As shown in Figure 5, telomerase acti vity was detectable (lane 1), al though efficiency of primer elongation was decreased substantially compared to extension in the absence of telomere DN A-binding protein (lane 6). When tel omere protein was incubated with the telomerase-telomeric

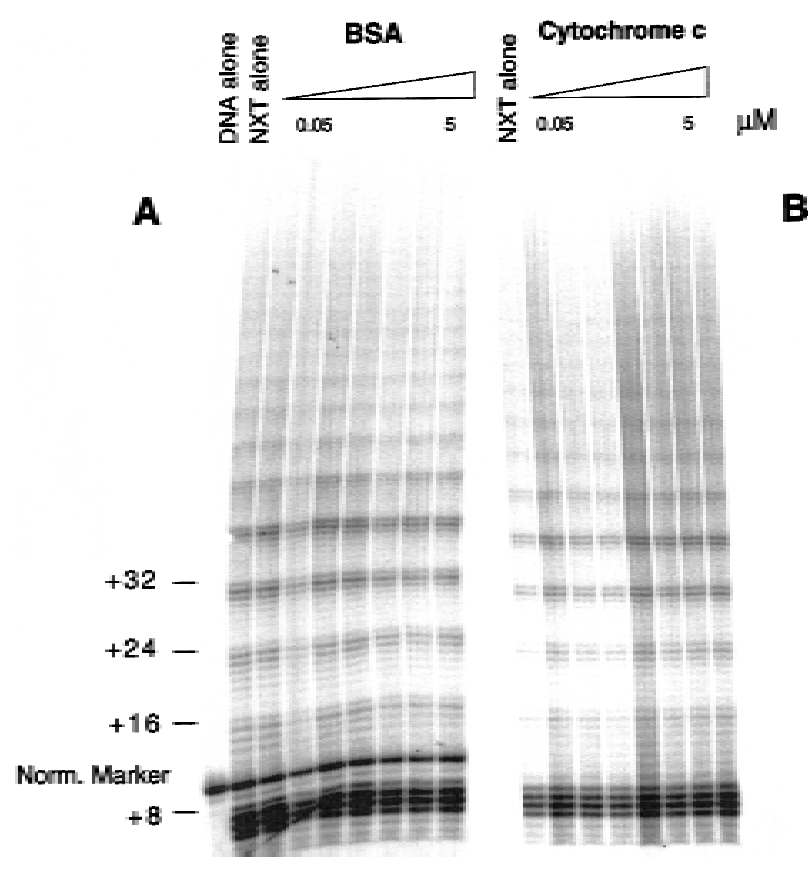

Figure 4. The effects on telomerase activity are tel omere protein specific. Telomerase el ongation was monitored in the presence of BSA (A) and the more basic cytochrome $c(B)$. Both were preincubated with the DNA substrate $\left(\mathrm{T}_{4} \mathrm{G}_{4}\right)_{2}$ at the following concentrations: $0.5,0.1,0.25,0.5,1,2.5$, and $5 \mu \mathrm{m}$. In the BSA experiment, a 25-mer 5'-radiolabel ed oligonucleotide was added as a size marker and internal normalization standard.

DNA complex before reaction initiation, el ongation of the telomeric DNA in both the ternary complex and the $\alpha \cdot$ DNA $\cdot \alpha$ complex was eliminated (Fig. 5, lane 2,3,5). In contrast, the $\alpha$. DN A complex permitted DNA elongation (Fig. 5, lane 4).

These results indicate that telomere protein subunits are able to displace telomerase. It is also possible that telomerase is dissociating from the telomeric DNA and allowing access by the telomere proteins. Then, if the binding proteins have a greater affinity for the telomeric DNA, they will not be displaced by telomerase. However, this cannot be the sole explanation as processive elongation (repetitive rounds of replication without dissociation) occurs in the absence of the telomere protein subunits (see Fig. 3; data not shown; for a detailed study with Euplotes aediculatus, see Hammond et al. 1997). Theinhibition of ongoing processive elongation by two $\alpha$ subunits or $\alpha+\beta$ suggests that these proteins actively displace tel omerase.

The $\alpha$ subunit as a length regulator

The observation that the $\alpha$. DNA complex allows tel omerase-mediated extension, whereas the presence of two $\alpha$ subunits inhibits tel omerase, suggested a role for the $\alpha$ subunit in telomere length regulation. To investigate this possibility further, the oligonucleotide $A_{8} T_{4} G_{4}$ 


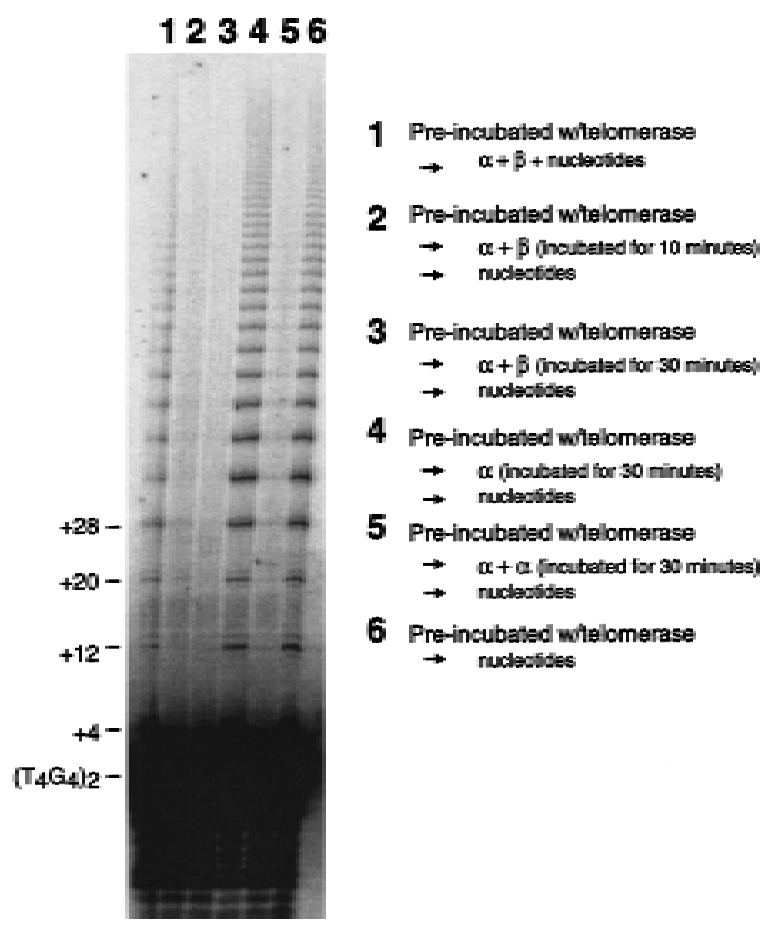

Figure 5. Telomere proteins are able to displace telomerase at the telomeric terminus. Telomerase was preincubated with the 5 '-end-label ed oligonucleotide substrate $\left(T_{4} G_{4}\right)_{2}$ for $10 \mathrm{~min}$ before the addition of telomere-binding protein subunits and nucleotides or nucleotide al one. Lane description can be found within the figure. "N ucleotides" refers to dGTP and dTTP. The concentrations of the $\alpha+\beta$ subunit were $1 \mu \mathrm{M}$ in lanes 1-3; the concentration of the $\alpha$ subunit was $100 \mathrm{~nm}$ in lane 4 , and $2.5 \mu \mathrm{m}$ in lane 5 . The identification of the +4 extension product was based on a lighter exposure.

was extended in the presence of increasing concentrations of the $\alpha$ subunit (Fig. 6). The rationale was that extension by one repeat ( 8 nucleotides) would enable two $\alpha$ subunits to be bound, at which point el ongation would be terminated. Instead, at concentrations where the second $\alpha$ subunit is bound, it appeared that telomerase

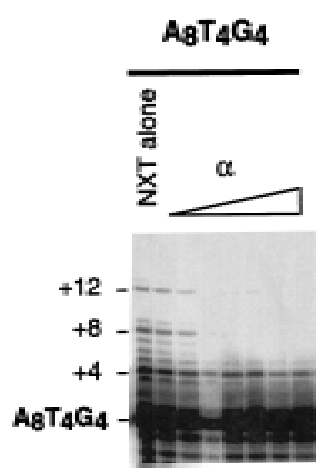

Figure 6. Extension of an oligonucleotide with one $\alpha$ binding register. 5'-Radiolabeled $A_{8} T_{4} G_{4}$ was incubated with $0.05,0.1$, $0.25,0.5,1,2.5$, and $5 \mu \mathrm{M} \alpha$ subunit, then with nuclear extract. Lane 4 represents a poor ethanol precipitation. added only 4 nucleotides and then halted (Fig. 6). One possible explanation is that a second $\alpha$ subunit may not require a full telomeric repeat for binding (i.e., 4 nucleotides could support a second subunit; for example, $2 \alpha$ subunits will bind to the $12-m e r G_{4} T_{4} G_{4} ;$ J.M. Bevilacqua and S.C. Schultz, unpubl.). In any case, the $\alpha$ subunit provides reasonably precise length regulation in vitro, but it is not the same specificity that would be sufficient to explain the presence of the 16-nucl eotide 3' overhang in vivo.

Telomerase is able to extend a telomeric substrate bound by a single $\alpha$ subunit

In the presence of the $\alpha$ subunit, at concentration ranges where the $\alpha$. DNA complex was visualized by gel-shift analysis, telomerase was able to extend the telomeric DN A substrate (see Fig. 3A). However, it was unclear whether the $\alpha$. DN A complex was extended, or whether the elongation was attributable to the inherent instability of the $\alpha$. DN A complex. The $\alpha$ off-rate is very rapid (half-life <1 min; Fang et al. 1993; data not shown), and thus, the extension of transiently "free" DNA is a possibility. To address this point, the $\alpha$ subunit was crosslinked to the telomeric DN A. To monitor cross-linking efficiency, the DNA substrate was 5'-radiolabeled and incubated with increasing concentrations of the $\alpha$ subunit. The samples were irradiated, and the formation of the $\alpha$-DN A and $\alpha$-DN A- $\alpha$ complexes (where dashes represent covalent linkage) was monitored by denaturing gel electrophoresis (Fig. 7A).

To determine whether telomerase is abl e to extend the cross-linked complexes, unlabeled DNA substrate

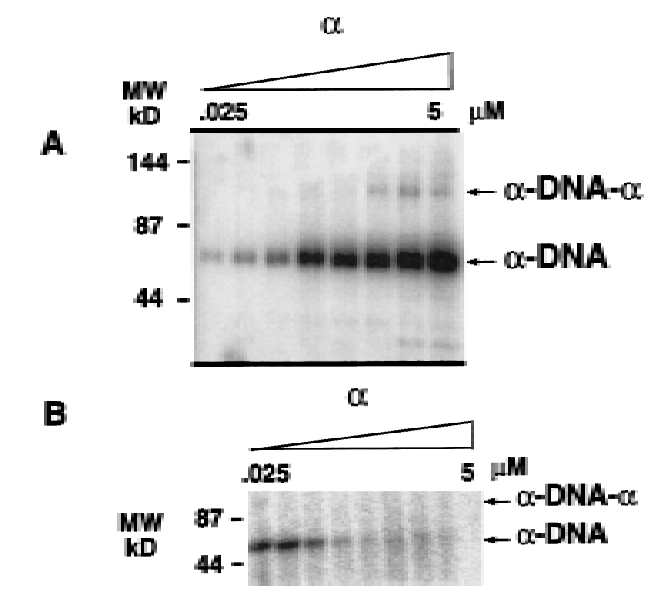

Figure 7. Cross-linking of the $\alpha$ subunit to the DNA substrate $\left(\mathrm{T}_{4} \mathrm{G}_{4}\right)_{2}$. (A) To monitor complex formation, the DNA was $5^{\prime}-$ radiolabeled, incubated with the $\alpha$ subunit, and cross-linked. Cross-linked complexes were monitored by denaturing polyacrylamide gel electrophoresis. (B) To evaluate whether the $\alpha$ DNA and $\alpha$-DNA- $\alpha$ cross-linked complexes were extended by telomerase, increasing concentrations of the $\alpha$ subunit were cross-linked to nonlabeled DNA. ${ }^{32} \mathrm{P}$-Radiolabeled nucleotides and nuclear extract were added, and the label incorporation into the complexes was monitored by gel el ectrophoresis. 
$\left(T_{4} G_{4}\right)_{2}$ was cross-linked to the $\alpha$ subunit; telomerasecontaining extract and radiol abel ed nucl eotide were then added, and the complexes were analyzed by gel el ectrophoresis. Incorporation of I abel ed nucl eotide into the $\alpha$ DNA complex indicated that the complex was a substrate for telomerase, whereas there was no incorporation of nucleotide in the $\alpha$-DNA- $\alpha$ complex (Fig. 7B). The inhibition of telomerase extension seen at higher $\alpha$ subunit concentrations in Figure $7 \mathrm{~B}$ is explained by the formation of the $\alpha \cdot$ DNA $\cdot \alpha$ complexes, which are not substrates for telomerase. The $\alpha \cdot$ DNA $\cdot \alpha$ complexes are usually cross-linked only once, and therefore, run as $\alpha$. DN A complexes in the denaturing gel. This explains the large abundance of the $\alpha$-DNA complex in Figure 7A.

The telomere-binding protein subunits inhibit extension by another DNA polymerase

To evaluate whether the telomere protein subunits modulate telomerase activity specifically or whether binding of the subunits also affects other polymerases, the activity of calf thymus terminal deoxynucleotidyltransferase $(T d T)$ was analyzed. Unlabeled $\left(T_{4} G_{4}\right)_{2}$ was incubated with telomere protein subunits followed by the addition of enzyme and radiol abel ed dTTP. N ucleotide addition by TdT was monitored (Fig. 8). Previously, Shippen et al. (1994) reported that the native $\alpha \cdot \beta$ telomere protein complex inhibited DN A extension by TdT. Consistent with these results, the recombinant telomere protein subunits in the ternary complex inhibited TdT activity (Fig. 8). The $\alpha$. DNA - $\alpha$ complex al so abolished elongation; however, TdT was able to access its substrate when bound by a single $\alpha$ subunit (Fig. 8).

Because the telomere DN A-binding protein subunits inhibit both $\mathrm{TdT}$ and telomerase, these data suggest that the telomere proteins are inhibitory in a substrate-specific fashion rather than by distinct protein-protein interactions. This conclusion is further supported by the fact that the initial rate of tel omerase elongation was not altered significantly when one $\alpha$ subunit was bound. Thus, we propose that the telomere protein subunits regulate telomerase in vitro by controlling the accessibility of the telomeric DNA substrate.

\section{Justification for use of a heterologous system}

Because of recent difficulties in extracting active telomerase from $\mathrm{O}$. nova cells, telomerase-containing nucl ear extract was prepared from the closely related $\mathrm{O}$. trifallax. Accordingly, all experiments described thus far were performed with $\mathrm{O}$. trifall ax tel omerase and $\mathrm{O}$. nova telomere protein. Although the $\mathrm{O}$. trifallax telomere proteins have not been purified, their gene sequences have been determined (DuBois and Prescott 1997). The derived amino acid sequences of the $O$. trifallax and $O$. nova telomere DNA-binding proteins are $80 \%$ identical and $90 \%$ similar, with the differing amino acids dispersed throughout the proteins. To ascertain whether the species difference was affecting the observed results,
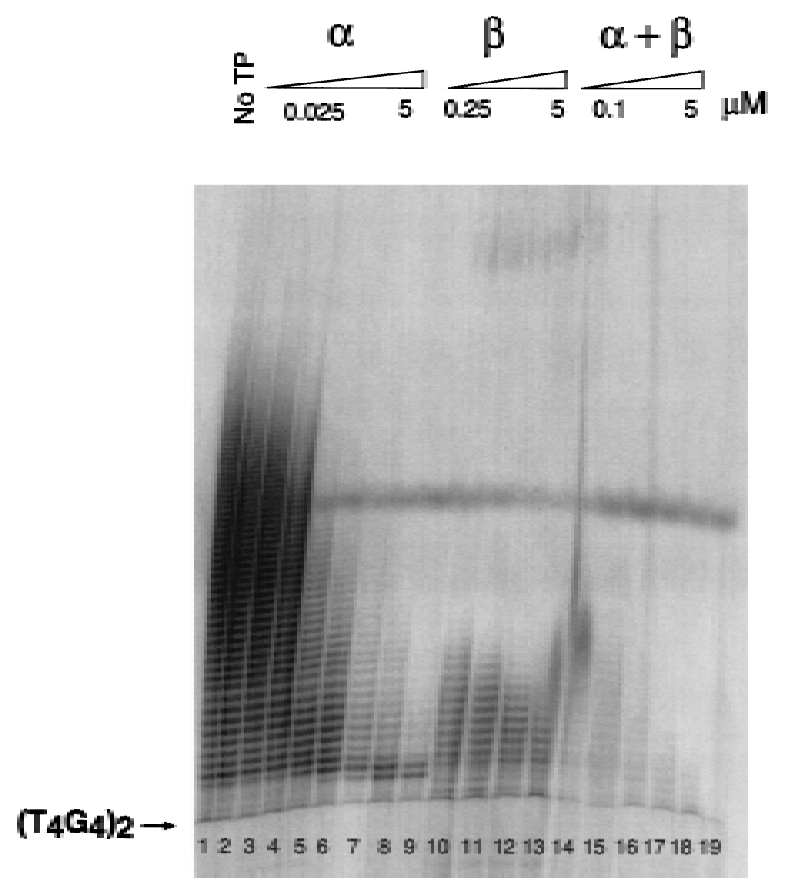

Figure 8. Telomere proteins modulate TdT activity. Telomere protein subunits were prebound to DN A followed by the addition of TdT. (Lane 1) The activity of TdT in the absence of telomere protein (TP) subunits; (lanes 2-9) $\alpha$ subunit was present at $0.025,0.05,0.1,0.25,0.5,1,2.5$, and $5 \mu \mathrm{m}$; (lanes 10-14) the $\beta$ subunit was present at $0.1,0.25,0.5,1$, and $5 \mu \mathrm{m}$; and (lanes 15-19) the ternary complex was formed in the presence of $0.1,0.25,0.5,1$, and $5 \mu \mathrm{m}$ of each subunit.

several tests were performed. The telomerase ribonucleoprotein complexes from $\mathrm{O}$. nova and $\mathrm{O}$. trifallax were compared by native gel analysis. The apparent size and charge of the two compl exes were indistinguishable (Fig. 9A). An E. aediculatus extract included for comparison showed a higher mobility tel omerase ribonucl eoprotein complex. In addition, an assay was performed in a homologous system with $O$. nova nuclear extract isolated previously (Lingner et al. 1994). The effect of theO. nova tel omere proteins on $\mathrm{O}$. nova telomerase activity was anal ogous to that obtained in the heterologous experiments (cf. Fig. 9B and Fig. 3A). As in Figure 3, $\alpha+$ full-length $\beta$ was inhibitory at a lower concentration than $\alpha+\beta_{\Delta C 260}$. From these results, it is clear that the tel omerase and tel omere proteins from these two species are very similar. Hence, it is unlikely that the use of the heterologous system influenced our results.

\section{Discussion}

Although there is no evidence for a conserved sequence motif or superfamily of single-stranded DNA-binding telomere proteins, it is likely that the functional properties are conserved. These proteins are thought to be crucial in the protection of telomeric DNA, but they may also participate in other aspects of telomere function (Fang and Cech 1995a; Lin and Zakian 1996; N ugent et 

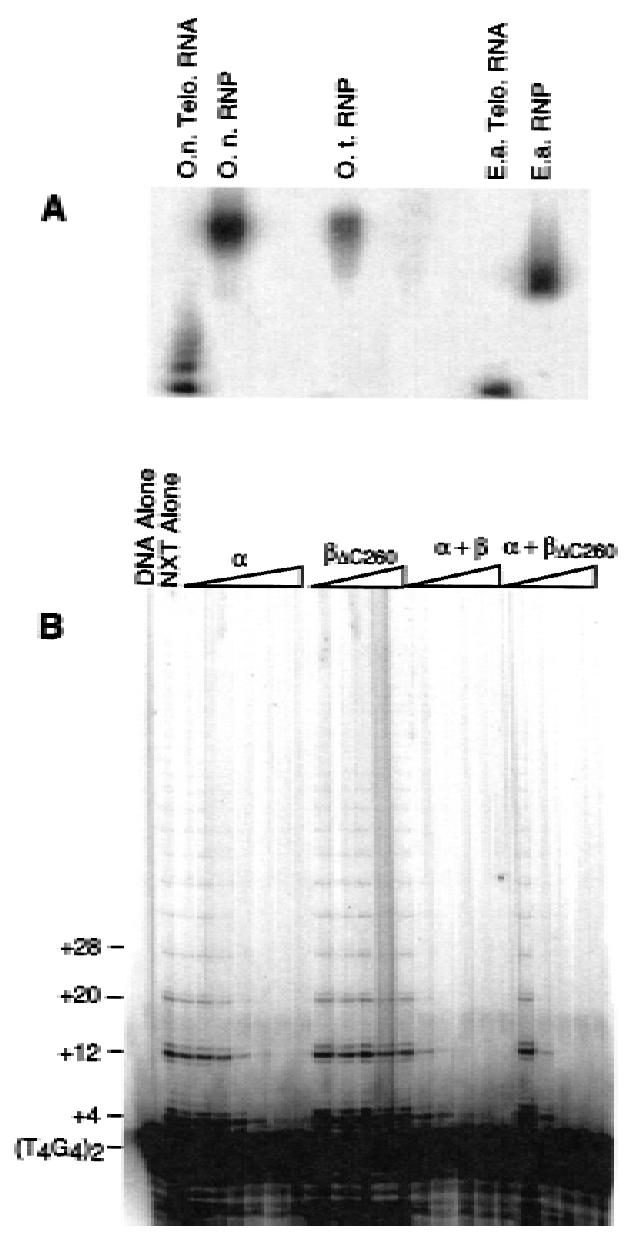

Figure 9. Analogous studies with a homologous system. (A) The tel omerase ribonucleoprotein (RNP) complexes were compared on a native agarose gel visualized by $\mathrm{N}$ orthern hybridization to the RNA subunits. (O.t.) Oxytricha trifallax; (O.n.) Oxytricha nova; (E.a.) Euplotes aediculatus. (B) The extension efficiency of $O$. nova tel omerase was measured in the presence of $\mathrm{O}$. nova tel omere proteins. Protein concentrations are identical to those in Fig. 3. al. 1996), as has been found for double-stranded DNAbinding telomere proteins (Krauskopf and Blackburn 1996; Cooper et al. 1997; Marcand et al. 1997; van Steensel and de Lange 1997). One of these roles may be the regulation of tel omerase. Because it now appears that a single-stranded telomeric overhang is a conserved feature of eukaryotic chromosomes (see introductory section), it may be generally true that singlestranded telomere DNA-binding proteins coordinate their efforts with telomerase for the length regulation and maintenance of the telomere. To characterize further the effects of single-stranded DNA-binding telomere proteins on telomerase activity, the present study eval uated the interaction of purified Oxytricha $\alpha$ and $\beta$ subunits with telomerase. The results are summarized in the model depicted in Figure 10A.

On the basis of the results presented, it appears that telomeric DNA bound to one $\alpha$ subunit can provide a substrate for efficient tel omerase extension. This is true even if $\alpha$ is bound to the 3 '-terminal repeat (Fig. 6). In addition, the $\alpha$ subunit may contribute to length regulation. After initiation and addition of a minimal binding site ( 4-8 nucleotides) by telomerase, one $\alpha$ subunit is bound, which still allows further extension by telomerase. Once another 8-base repeat is added (i.e., the physiological length of the telomeric overhang is achieved), a second $\alpha$ subunit binds, tel omerase is displaced, and extension is halted. The $\beta$ subunit can then displace one $\alpha$ subunit and a stable ternary complex is formed, protecting the telomere. This model (Fig. 10B) is supported by the following evidence: the $\alpha \cdot$ DNA $\cdot \alpha$ does not allow telomerase elongation of telomeric DNA and the $\alpha \cdot$ DNA $\cdot \alpha$ complex is able to displace telomerase. Although binding of two $\alpha$ subunits resulted in a defined telomere length in vitro, it produced a 12-nucleotide telomeric tract instead of the 16-nucleotide extension present in the in vivo steady state; thus, our in vitro system does not fully recapitulate telomere length regulation.

There is no direct evidence for the formation of the $\alpha \cdot$ DNA $\cdot \alpha$ complex in vivo. However, it seems very
A

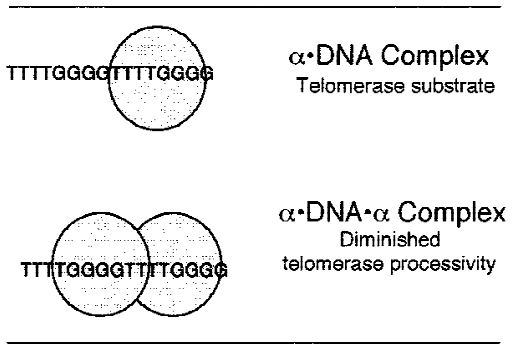
length regulation. (A) The effects of telomere protein subunits on telomerase elongation of telomeric DNA are summarized schematically. The $\alpha$ subunit is light gray and hatched, whereas the $\beta$ subunit is a darker gray and striped. (B) A proposed model for the in vivo telomere protein involvement in telomere length regulation. Exactly when telomere proteins bind relative to telomerase extension is speculative.

-

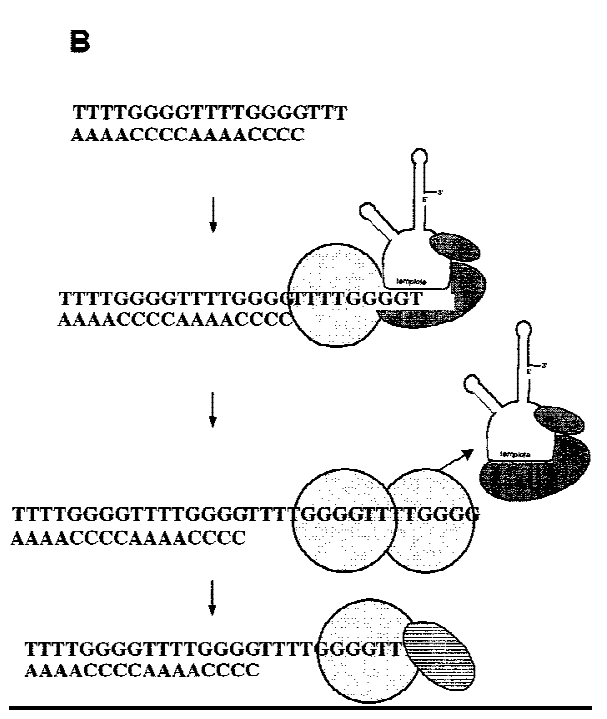


likely to exist as an intermediate in ternary complex formation, because (1) the $\alpha$ and $\beta$ subunits do not form a stable heterodi mer in the absence of DNA, but instead bind individually and form a heterodimer on the DNA (Fang and Cech 1993b), and (2) during in vitro reconstitution, the formation of the $\alpha \cdot$ DNA $\cdot \alpha$ complex precedes that of $\alpha \cdot \beta \cdot$ DNA (J.M. Bevilacqua and S.C. Schultz, unpubl.). Binding of the $\alpha$ subunit could serve as a mechanism to count the repeats in the single-stranded regi on of the tel omere, perhaps by inducing a conformational change in the telomeric DNA. It has been proposed that telomere length in yeast is determined not so much by governing telomerase, but rather by counting the number of Rapl proteins bound (Marcand et al. 1997), with special importance of Raplp binding to the sequence repeat at the very end of the telomeric tract (Krauskopf and Blackburn 1996). Because of the consistent maintenance of a defined telomere length in Oxytricha, this could also be the case with the $\alpha$ subunit.

Shippen et al. (1994) first addressed Oxytricha telomerase $\cdot$ tel omere protein interactions, and reported that telomerase was able to extend the $\alpha \cdot \beta \cdot$ DN A complex. Unlike the current report, native rather than recombinant proteins were used, and telomere protein complex integrity during extension was not defined. There are two feasible, and not mutually exclusive, explanations for the different resul ts found in the two studies. First, the $\beta$ subunit is particularly susceptible to proteolytic digestion (Gottschling and Zakian 1986; Price and Cech 1987), and thus in a native protein system, there could be insufficient $\beta$ to maintain all the DNA in ternary complexes. Thus, Shippen et al. (1994) might have been observing extension of $\alpha$. DNA complexes, which we also show to be substrates for telomerase. Consistent with this interpretation, Shippen et al. suggest that their telomere complexes may exist in different populations that have different accessibility to telomerase. Second, the native proteins are known to be posttranslationally modified (Hicke et al . 1995), and it is possible that such modification could activate the ternary complex for extension by telomerase through a conformational change or protein dissociation. Recombinant proteins presumably lack these modifications. Thus, the effect of protein modifications on the accessibility of the telomere to telomerase remains to be investigated.

We find that the $\alpha \cdot \beta \cdot$ DNA complex, reconstituted from purified recombinant proteins, is not a substrate for telomerase. M ost telomeres exist as an $\alpha \cdot \beta \cdot$ DN A complex in vivo (Price and Cech 1987; Gray et al. 1991). How, then, does telomerase gain access to its telomeric DNA substrate to permit the next round of DNA replication? It cannot wait for protein dissociation, as the ternary complex has a half-life of $\sim 100 \mathrm{hr}$ in vitro (Fang et al. 1993), which is much longer than the Oxytricha cell cycle (6-8 hr). Cell-cycle-regulated post-translational modification of the protein (Hicke et al. 1995), degradation of one or both subunits, or even active removal by another enzyme are all conceivable solutions to this problem.
Because the $\alpha \cdot \beta \cdot$ DNA complex is inhibitory for DN A extension mediated by TdT as well as telomerase, it is evident that these telomere proteins are acting by binding to the substrate rather than by a specific proteinprotein interaction. In addition, when a single $\alpha$ subunit is bound, the initial rate of telomerase extension is not affected (data not shown), which demonstrates that the subunit can bind in such a way to allow accessibility of the telomeric $3^{\prime}$ terminus to telomerase.

In summary, the evi dence presented here suggests that single-stranded telomeric DNA-binding proteins may contribute to telomere length regulation by interacting with the chromosome end and thereby repressing tel omerase.

\section{Materials and methods}

\section{Oligonucleotides and clones}

DNA oligonucleotides were synthesized and purified on denaturing polyacrylamide gels. For tel omerase assays, oligonucleotides were $5^{\prime}$-end labeled by incubating at $37^{\circ} \mathrm{C}$ for $30 \mathrm{~min}$ in $10-\mu$ reactions containing 20 pmoles of oligonucleotide, 10 units of $\mathrm{T} 4$ polynucl eotide kinase ( $\mathrm{N}$ ew Engl and Biolabs), $1 \mu \mathrm{l}$ of $10 \times$ PN K buffer (commercially supplied, $\mathrm{N}$ ew England Biolabs), $1 \mu \mathrm{l}\left[\alpha-{ }^{32} \mathrm{P}\right] A T P[150 \mathrm{mCi} / \mathrm{ml}, 6000 \mathrm{Ci} / \mathrm{mmol}$; $\mathrm{New}$ England Nuclear (NEN)]. Radiolabeled oligonucleotide was separated from unincorporated nucleotides by Sephadex-G25 chromatography. The primary oligonucleotide sequence used in these experiments was $5^{\prime}$-TTTTGGGGTTTTGGGG-3', the sequence of the native Oxytricha single-stranded telomere overhang. Other oligonucleotides used are denoted in the figure legends or the text.

The N orthern hybridization probes for Figure 9 were DNA fragments complementary to the telomerase RNAs for those species. Fragments were obtained by excising the sequence from a cloned plasmid ( $\mathrm{O}$. nova and $\mathrm{E}$. aediculatus; Lingner et al. 1994), or by PCR (O. trifallax). In all cases, the fragment was radiolabeled as follows: DN A was denatured by heating at $95^{\circ} \mathrm{C}$ for $5 \mathrm{~min}$ and brief ice-water cooling for $1 \mathrm{~min}$, then $5 \mu \mathrm{l}$ of $\left[\alpha^{32} \mathrm{P}\right] \mathrm{dCTP}(3000 \mathrm{Ci} / \mathrm{mmole}, 40 \mathrm{mCi} / \mathrm{ml}$; Easytide N EN ) and 5 $\mu$ of High Prime (Boehringer $M$ annheim) were added. Labeling proceeded at $37^{\circ} \mathrm{C}$ for $30 \mathrm{~min}$. Label ed DN A was separated from unincorporated nucleotides by Sephadex-G25 chromatography. Before addition to native gel blots, the labeled DNA probe was denatured as outlined above.

Purification of the telomere protein subunits $\alpha$ and $\beta$

The purification protocol was developed by J.A. Ruggles and S.C. Schultz (unpubl.). Basically, 6 liters of BL21 plysS Escherichia coli cells containing the plasmids p56a and p4la (encoding the $\alpha$ and $\beta$ genes, respectively) were grown for $\sim 2 \mathrm{hr}$ at $37^{\circ} \mathrm{C}$ (to an $\mathrm{OD}_{600} \cong 0.3$ or 0.4 ). Cultures were then shifted to $25^{\circ} \mathrm{C}$ and cooled for $\sim 1 \mathrm{hr}$. IPT G $(0.5 \mathrm{~mm})$ was added to induce protein expression. After a 6-hr induction, cells were harvested by centrifugation $(10 \mathrm{~min}$ at $4000 \mathrm{rpm})$ and frozen at $-20^{\circ} \mathrm{C}$. Cells were lysed by thawing in $50 \mathrm{~mm}$ HEPES (pH 7.5), $50 \mathrm{~mm} \mathrm{~N} \mathrm{aCl}, 0.02 \%$ $\mathrm{NaN}_{3}$, and $1 \mathrm{~mm} \mathrm{NaEDTA}$; the cell mix was sonicated for three 40-sec bursts to break remaining intact cell walls and to eliminate higher order chromosomal structure. Cell debris was removed by centrifugation (30 min at $12,000 \mathrm{rpm}$ ). Ammonium sulfate precipitations $(35 \%$ and $70 \%)$ were performed and the final supernatant was dialyzed. The $\alpha$ subunit was further pu- 
rified by FPLC with sequential chromatography on S-Sepharose, Q-Sepharose and a final sizing column. The $\beta$ and $\beta_{\Delta C 260}$ subunits were further purified by FPLC using S-Sepharose and a sizing column. Samples were dialyzed, concentrated (if needed), and filtered before each column chromatography step. Protein integrity was determined by Coomassie-stained SDS-PAGE and Western blot analysis, and proteins were found to be $>95 \%$ homogeneous. Protein concentration was determined by Bradford colorimetric assay (Bio-Rad).

\section{Growth of O. trifallax}

O. trifallax was grown as described previously (Swanton et al. 1980) under nonsterile conditions with Chlorogonium as the food source. Growth was conducted in glass baking dishes at room temperature.

\section{Preparation of nuclear extract}

$\mathrm{N}$ uclear extracts were prepared by a modified version of a previously described protocol (Lingner et al. 1994). Cells were isolated and concentrated by multiple-step filtration using $10 \mu \mathrm{m}$ $\mathrm{N}$ ytex filters, and harvested by centrifugation for $2 \mathrm{~min}$ at 2000 rpm at $4^{\circ} \mathrm{C}$ in a low speed clinical centrifuge. Cells were lysed using an overhead stirring rod in 1\% NP-40 in the presence of $0.5 \mathrm{mg} / \mathrm{ml}$ spermidine phosphate, $0.5 \mathrm{~mm}$ PMSF, $10 \mathrm{~mm}$ Trisacetate, and $10 \mathrm{mM} \mathrm{M} \mathrm{gCl}_{2}$. N uclei were isolated by centrifugation through $10 \%$ sucrose at $7500 \mathrm{rpm}$ for $10 \mathrm{~min}$. The nuclei were washed once to remove further cellular debris. N uclear yield and integrity were monitored under the microscope using $5 \%$ acetocarmine. The nuclei were then lysed in $500 \mu \mathrm{l} / 10$ grams cells of the foll owing buffer: $50 \mathrm{~mm}$ Tris-acetate (pH 7.5), $10 \mathrm{mM} \mathrm{M} \mathrm{gCl}, 10 \%$ glycerol, $0.1 \%$ NP-40, $0.5 \mathrm{~mm} \mathrm{PMSF}$, and 0.4 M K-glutamate. Homogenization (25 strokes) in a 2-ml glass Dounce aided the salt lysis. The nuclear membrane and debris were pelleted by microcentrifugation at $14,000 \mathrm{rpm}$ for $30 \mathrm{~min}$. Supernatant was isolated, quick frozen in liquid $\mathrm{N}_{2}$, and stored at $-80^{\circ} \mathrm{C}$. Extracts exhibited activity for several months.

\section{Gel-shift analysis of telomere protein complex formation}

Telomere protein complex formation was monitored by a novel horizontal agarose gel system first devel oped by J.M. Bevilacqua and S.C. Schultz (unpubl.) and further optimized for these studies. The telomere protein subunits were preincubated with $5^{\prime}$ radiolabel ed substrate at $4^{\circ} \mathrm{C}$ overnight or at $25^{\circ} \mathrm{C}$ for $1-2 \mathrm{hr}$ in $20 \mathrm{~mm}$ HEPES (pH 7.5), $1 \mathrm{~mm}$ EDTA, $200 \mathrm{~mm} \mathrm{NaCl}$, and 2.5\% NP-40. Reactions were then electrophoresed on a $1 \%$ agarose gel $(0.4 \mathrm{~cm}$ thick, $10 \mathrm{~cm}$ long, $15 \mathrm{~cm}$ wide) buffered by $40 \mathrm{~mm}$ Tris-bis propane-acetate $(\mathrm{pH} 7.0), 1 \mathrm{~mm}$ EDTA at $4^{\circ} \mathrm{C}$. The samples were loaded in the middle of the gel such that the positively charged complexes and free protein migrated in the opposite direction as the negatively charged unbound DN A substrate. Gels were electrophoresed at $90 \mathrm{~V}$ for $\sim 2 \mathrm{hr}$. Gels were dried on Hybond $\mathrm{N}+$ membranes to minimize loss of DNA and analyzed using a Phosphorlmager or by autoradiography.

\section{Telomerase activity assays}

In vitro telomerase activity was evaluated by monitoring the addition of nucleotides to an oligonucleotide substrate. Assays followed the basic outline described previously by Lingner et al . (1994). Two variations were used. In the first, $0.5 \mathrm{~nm}$ of 5 'radiolabeled oligonucleotide was incubated with telomerasecontaining nuclear extract and $125 \mu \mathrm{M}$ dGTP and dTTP, in telomerase assay buffer ( $1 \mathrm{~mm} \mathrm{M} \mathrm{MCl}_{2}, 1 \mathrm{~mm}$ DTT, $50 \mathrm{~mm} \mathrm{~K}$ - glutamate, and $20 \mathrm{~mm}$ Tris-acetate). Alternatively, $25 \mathrm{~nm}$ nonlabel ed oligonucleotide was incubated with telomerase, dGTP, and $\left[\alpha^{-}{ }^{32} \mathrm{P}\right] \mathrm{dTTP}(400 \mathrm{Ci} / \mathrm{mmole}, 10 \mathrm{mCi} / \mathrm{ml}$; Amersham) in telomerase assay buffer. For telomerase elongation, samples were incubated at $25^{\circ} \mathrm{C}$ for $30 \mathrm{~min}$, unless otherwise indicated. When tel omere protein was present in the activity assays, complexes were formed as described above, followed by the addition of telomerase. Analogous methodology was used when the effects of BSA and cytochrome c on tel omerase activity were studied. Reactions were terminated by the addition of stop solution [10 mM Tris- $\mathrm{HCl}(\mathrm{pH} 7.5), 15 \mathrm{~mm}$ EDTA, 0.6\% SDS, and 0.1 $\mathrm{mg} / \mathrm{ml}$ proteinase $\mathrm{K}$ ] and incubated at $45^{\circ} \mathrm{C}$. In standard reaction, proteinase $K$ digestion was conducted for $30 \mathrm{~min}$, but in cases where telomere protein was present, the time of incubation was increased to $2 \mathrm{hr}$. The samples were then ethanol precipitated after the addition of $\mathrm{Na}$ acetate (final concentration, $250 \mathrm{~mm}$ ) and $\sim 20 \mu \mathrm{g}$ of glycogen (Boehringer Mannheim), followed by a $70 \%$ ethanol wash. The DNA pellet was dried, resuspended in loading dye (90\% formamide, $0.5 \times$ TBE, $0.05 \%$ bromophenol blue and xylene cyanol), and heated at $50^{\circ} \mathrm{C}$ for 5 min. Samples were electrophoresed on an $8 \%$ polyacrylamide/ 7 M urea/ $1 \times$ TBE sequencing gel. The gel was dried and subjected to Phosphorlmager analysis. For quantification purposes, a radi ol abel ed ol igonucl eotide standard was added to reactions after termination but before ethanol precipitation to provide an internal normalization marker to combat the occasional inconsistencies prone to ethanol precipitations.

In "order of addition" experiments, tel omerase was incubated with the DN A substrate for $10 \mathrm{~min}$ at $25^{\circ} \mathrm{C}$ to al low association, followed by the addition of tel omere protein and nucleotides to initiate extension. Telomere protein incubations were done at $25^{\circ} \mathrm{C}$ for the denoted times. Once extension was initiated by the addition of nucleotides, the reactions proceeded as described previously.

\section{TdT assay}

The effect of telomere DNA-binding proteins on the extension efficiency of TdT ( $\mathrm{N}$ ew England Biolabs) was investigated in a manner as similar to telomerase activity assays as possible, although the reaction buffer was optimized for TdT activity. Telomere protein complex formation in this buffer was confirmed by agarose gel electrophoresis (data not shown). Telomere protein subunits were incubated with the DNA substrate $\left(\mathrm{T}_{4} \mathrm{G}_{4}\right)_{2}$ overnight at $4^{\circ} \mathrm{C}$ in $1 \times \mathrm{TdT}$ buffer ( $\mathrm{New}$ England Biolabs). TdT (5 units) and $1 \mu \mathrm{l}$ of $\left[\alpha^{-}{ }^{32} \mathrm{P}\right] \mathrm{dTT} \mathrm{P}(400 \mathrm{Ci} / \mathrm{mmole}, 10 \mathrm{mCi} / \mathrm{ml}$; $\mathrm{Am}-$ ersham) were added to a final volume of $40 \mu \mathrm{l}$, and the reaction mix was placed at $37^{\circ} \mathrm{C}$ for $1 \mathrm{hr}$. Reactions were terminated by the addition of $200 \mu \mathrm{l}$ of stop solution (see above) and incubated for $2 \mathrm{hr}$ at $45^{\circ} \mathrm{C}$. Elongation products were analyzed by $8 \%$ polyacrylamide/ 7 m urea/ 1 XTBE sequencing gel electrophoresis.

\section{Cross-linking of the $\alpha$ subunit to DNA}

To form a covalent $\alpha$-DN A complex, the $\alpha$ subunit was crosslinked to its DNA substrate (Hammond et al. 1997). Various concentrations of $\alpha$ were preincubated with 5 '-radiolabel ed oligonucleotide in a final volume of $10 \mu \mathrm{l}$. After a 2-hr incubation, the reactions were spotted on Parafilm stretched over a metal block placed on ice. The samples were irradiated $\sim 12 \mathrm{~cm}$ from the bulbs for $20 \mathrm{~min}$ at $312 \mathrm{~nm}$ in a Stratalinker 1800 (Stratagene). The reactions were stopped by the addition of $5 \mu \mathrm{l}$ of stop buffer [187 $\mu \mathrm{M}$ Tris- $\mathrm{HCl}$ (pH 6.8), 30\% glycerol, 6\% SDS, $0.075 \%$ bromophenol blue]. The samples were heated at $95^{\circ} \mathrm{C}$ for $3 \mathrm{~min}$ and complex formation was monitored by gel el ectrophoresis on $4 \%-20 \%$ N ovex gradient gels in Tris-glycine-SDS 
buffer. M olecular weight markers (Bio-Rad) were included. The gels were dried and Phosphorlmager analysis was performed.

In experiments in which the ability of telomerase to extend the $\alpha$-DN A cross-linked complex was tested, the $\alpha$ subunit was cross-linked to unlabeled DNA. After cross-linking, $[\alpha-$ ${ }^{32}$ P]dTTP (400 Ci/mmole, $10 \mathrm{mCi} / \mathrm{ml}$; Amersham), ddGTP and tel omerase were added and the samples were incubated at $25^{\circ} \mathrm{C}$ for $30 \mathrm{~min}$. The reactions were halted by the addition of stop buffer (see above). The reactions were then centrifuged through a Centricon-30 concentrator (Amicon) to remove unincorporated nucleotides and extended unbound oligonucleotide. The eluent was analyzed by gel electrophoresis as described above. Any incorporated label at the appropriate molecular weight represents complex that was extended.

\section{Native gel analysis of RNP complex formation}

$\mathrm{N}$ ondenaturing $1 \%$ agarose gels were run in $75 \mathrm{~mm}$ Tris-glycine buffer at $4^{\circ} \mathrm{C}$. Telomerase RN As from Oxytricha and Euplotes were run as standards. The gel was denatured in 50\% urea for 15 min and transferred to Hybond $\mathrm{N}+$ membrane (A mersham). After transfer, the blot was cross-linked at $254 \mathrm{~nm}$ and incubated at $65^{\circ} \mathrm{C}$ in Church buffer $\left(0.5 \mathrm{M} \mathrm{NaPO}_{4}, 1 \mathrm{~mm}\right.$ EDTA, $7 \%$ SDS, and $1 \%$ BSA) with radiolabeled denatured probe. The blot was hybridized overnight, washed thoroughly in $0.1 \% \mathrm{SDS} / 0.1 \times$ SSC, and analyzed using the Phosphorlmager.

\section{Acknowledgments}

We express our sincere thanks to David Prescott for the assistance in growing Oxytricha, for all the advice, and for the generous gift of cells; Joachim Lingner for DNA, O. nova nuclear extract, and discussion; Arthur Zaug and Phil Hammond for hel pful discussion; and Tracy Bryan and Jamie Sperger for critical reading of the manuscript. This research was supported in part by N ational Institutes of Health (N IH) grant GM 28039 to T.R.C. and by NIH grant AG11636 to S.C.S. S.J.F.A. was the recipient of an American Cancer Society Postdoctoral Fellowship. J.M.B. was the recipient of an $\mathrm{NIH}$ postdoctoral fellowship GM 17155. T.R.C. is an Investigator of the Howard Hughes Medical Institute and an American Cancer Society Professor.

The publication costs of this article were defrayed in part by payment of page charges. This article must therefore be hereby marked "advertisement" in accordance with 18 USC section 1734 solely to indicate this fact.

\section{References}

Blackburn, E.H. 1991. Structure and function of telomeres. Nature 350: 569-573.

-_-. 1992. Telomerases. Annu. Rev. Biochem. 61: 113-129.

Bodnar, A.G., M. Ouellette, M. Frolkis, S.E. Holt, C.-P. Chiu, G.B. Morin, C.B. Harley, J.W. Shay, S. Lichtsteiner, and W.E. Wright. 1998. Extension of lifespan in normal human cells by introduction of telomerase. Science 279: 349-352.

Brun, C., S. M arcand, and E. Gilson. 1997. Proteins that bind to double-stranded regions of telomeric DN A. Trends Cell Biol. 7: 317-324.

Cooper, J.P., E.R. Nimmo, R.C. Allshire, and T.R. Cech. 1997. Regulation of telomere length and function by a Myb-domain protein in fission yeast. Nature 385: 744-747.

DuBois, M.L. and D.M. Prescott. 1997. Volatility of internal el iminated segments in germ line genes of hypotrichous ciliates. Mol. Cell Biol. 17: 326-337.

Fang, G. and T.R. Cech. 1993a. Characterization of a G-quartet formation reaction promoted by the $\beta$ subunit of Oxytricha telomere-binding protein. Biochemistry 32: 11646-11657.

_-_. 1993b. Oxytricha telomere-binding protein: DNA-dependent dimerization of the $\alpha$ and $\beta$ subunits. Proc. Natl. Acad. Sci. 90: 6056-6060.

-_- 1995a. Telomere proteins. In Telomeres (ed. E. Blackburn and C. Greider), pp. 69-105. Cold Spring Harbor Laboratory Press, Cold Spring Harbor, NY.

- - - 1995b. Telomerase RNA in the replication band and spherical subnuclear organelles in hypotrichous ciliates. J. Cell Biol. 130: 243-253.

Fang, G., J.T. Gray, and T.R. Cech. 1993. Oxytricha telomerebinding protein: Separable DNA-binding and dimerization domains of the $\alpha$-subunit. Genes \& Dev. 7: 870-882.

Gottschling, D.E. and V.A. Zakian. 1986. Telomere proteins: Specific recognition and protection of the natural termini of Oxytricha macronuclear DNA. Cell 47: 195-205.

Gray, J.T., D.W. Celander, C.M. Price, and T.R. Cech. 1991. Cloning and expression of genes for the Oxytricha tel omerebinding protein: Specific subunit interactions in the telomeric complex. Cell 67: 807-814.

Greider, C.W. 1996. Telomere length regulation. Annu. Rev. Biochem. 65: 337-365.

Hammond, P.W., T.N. Lively, and T.R. Cech. 1997. The anchor site of telomerase from Euplotes aediculatus revealed by photo-cross-linking to single- and double-stranded DNA primers. Mol. Cell. Biol. 17: 296-308.

Harley, C.B. and B. Villeponteau. 1995. Telomeres and telomerase in aging and cancer. Curr. O pin. Genet. Dev. 5: 249255.

Hicke, B.J., D.W. Celander, G.H. MacDonald, C.M. Price, and T.R. Cech. 1990. Two versions of the gene encoding the 41-kilodalton subunit of the telomere binding protein of Oxytricha nova. Proc. Natl. Acad. Sci. 87: 1481-1485.

Hicke, B.J., R. Rempel, J. Maller, R. Swank, J. Hamaguchi, E.M. Bradbury, D.M. Prescott, and T.R. Cech. 1995. Phosphorylation of the Oxytricha telomere protein: Possible cell cycle regulation. Nucleic Acids Res. 23: 1887-1893.

Klobutcher, L.A., M.T. Swanton, P. Donini, and D.M. Prescott. 1981. All gene-sized DNA molecules in four species of hypotrichs have the same terminal sequence and an unusual $3^{\prime}$ terminus. Proc. Natl. Acad. Sci. 78: 3015-3019.

Krauskopf, A. and E.H. Blackburn. 1996. Control of telomere growth by interactions of RAP1 with the most distal telomeric repeats. Nature 383: 354-357.

Lin, J.J. and V.A. Zakian. 1996. The Saccharomyces CDC13 protein is a single-strand $\mathrm{TG}_{1-3}$ tel omeric DN A-binding protein in vitro that affects telomere behavior in vivo. Proc. Natl. Acad. Sci. 93: 13760-13765.

Lingner, J. and T.R. Cech. 1998. Telomerase and chromosome end maintenance. Curr. Opin. Genet. Dev. 8 (in press).

Lingner, J., L.L. Hendrick, and T.R. Cech. 1994. Telomerase RN As of different ciliates have a common secondary structure and a permuted template. Genes \& Dev. 8: 1984-1998.

Lundblad, V. and J. Szostak. 1989. A mutant with a defect in telomere elongation leads to senescence in yeast. Cell 57: 633-643.

M arcand, S., E. Gilson, and D. Shore. 1997. A protein-counting mechanism for telomere length regulation in yeast. Science 275: 986-990.

Makarov, V.L., Y. Hirose, and J.P. Langmore. 1997. Long G tails at both ends of human chromosomes suggest a $C$ strand degradation mechanism for telomere shortening. Cell 88: 657-666.

McElligott, R. and R.J. Wellinger. 1997. The terminal DNA structure of mammalian chromosomes. EMBO J. 16: 3705- 


\section{Froelich-Ammon et al.}

3714.

Nugent, C.I., T.R. Hughes, N.F. Lue, and V. Lundblad. 1996. Cdc13p: A single-strand telomeric DNA-binding protein with a dual role in yeast telomere maintenance. Science 274: 249-252.

Price, C.M. and T.R. Cech. 1987. Telomeric DNA-protein interactions of Oxytricha macronuclear DNA. Genes \& Dev. 1: 783-793.

Raghuraman, M.K. and T.R. Cech. 1990. Effect of monovalent cation-induced telomeric DNA structure on the binding of Oxytricha telomeric protein. Nucleic Acids Res. 18: 45434552.

Shippen, D.E., E.H. Blackburn, and C.M. Price. 1994. DN A bound by the Oxytricha telomere protein is accessible to telomerase and other DNA polymerases. Proc. Natl. Acad. Sci. 91: 405-409.

Skopp, R., W. Wang, and C. Price. 1996. rTP: A candidate telomere protein that is associated with DNA replication. Chromosoma 105: 82-91.

Swanton, M.T., A.F. Greslin, and D.M. Prescott. 1980. Arrangement of coding and non-coding sequences in the DN A molecules coding for rRNAs in Oxytricha sp. Chromosoma 77: 203-215.

van Steensel, B. and T. de Lange. 1997. Control of telomere length by the human telomeric protein TRF1. Nature 385: 740-743.

Wellinger, R.J., A.J. Wolf, and V.A. Zakian. 1993. Saccharomyces telomeres acquire single-strand $T G_{1-2}$ tails late in $S$ phase. Cell 72: 51-60.

Wellinger, R.J., K. Ethier, P. Labrecque, and V.A. Zakian. 1996. Evidence for a new step in telomere maintenance. Cell 85: 423-433.

Williamson, J.R. 1994. G-quartet structures in telomeric DNA. Annu. Rev. Biophys. Biomol. Struc. 23: 703-730.

Wright, W.E., V.M. Tesmer, K.E. Huffman, S.D. Levene, and J.W. Shay. 1997. Normal human chromosomes have long G-rich telomeric overhangs at one end. Genes \& Dev. 11: $2810-2821$.

Zahler, A.M., J.R. Williamson, T.R. Cech, and D.M. Prescott. 1991. Inhibition of tel omerase by G-quartet DN A structures. Nature 350: 718-720.

Zakian, V.A. 1989. Structure and function of telomeres. Annu. Rev. Genet. 23: 579-604.

- - 1995. Telomeres: Beginning to understand the end. Science 270: 1601-1607.

- - - 1996. Structure, function, and replication of Saccharomyces cerevisiae tel omeres. Annu. Rev. Genet. 30: 141-172. 


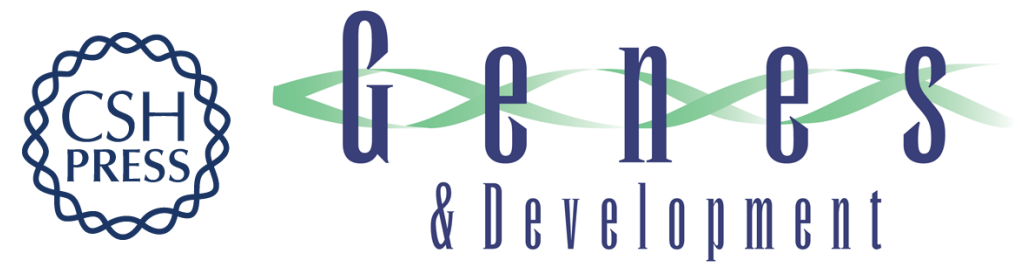

\section{Modulation of telomerase activity by telomere DNA-binding proteins in Oxytricha}

Stacie J. Froelich-Ammon, Brent A. Dickinson, Joanne M. Bevilacqua, et al.

Genes Dev. 1998, 12:

Access the most recent version at doi:10.1101/gad.12.10.1504

References

This article cites 39 articles, 17 of which can be accessed free at: http://genesdev.cshlp.org/content/12/10/1504.full.html\#ref-list-1

License

Email Alerting

Receive free email alerts when new articles cite this article - sign up in the box at the top Service right corner of the article or click here.

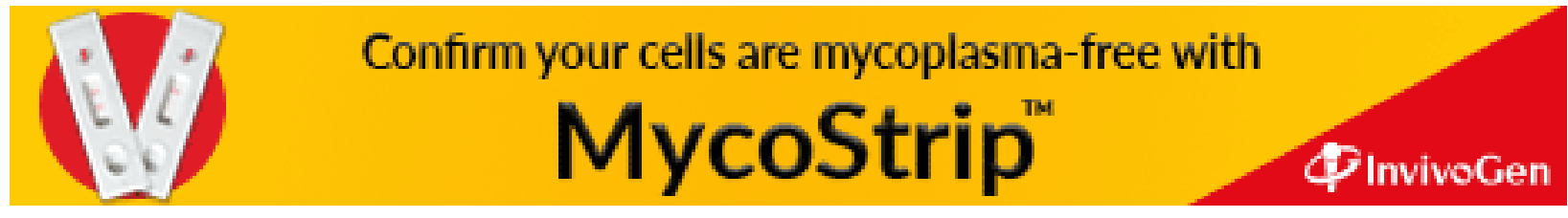

